\title{
Single cultivation versus sweet potato and popcorn intercropping: benefits over edaphic fauna in ecological-based system ${ }^{1}$
}

\author{
Marciel Redin ${ }^{2 *}$ D, Eduardo Canepelle ${ }^{2}$, Thaniel Carlson Writzl ${ }^{2}$, Danni Maisa da Silva ${ }^{2}$, \\ Divanilde Guerra ${ }^{2}$, Marta Sandra Drescher ${ }^{2}$
}

$10.1590 / 0034-737 X 202168050013$

\begin{abstract}
The objective of this study was to evaluate the diversity and abundance of edaphic fauna organisms in single and intercropped systems of sweet potato (Ipomoea batatas) and ecologically-based popcorn (Zea mays) in Red Oxisol, in the Northwest region of the state of Rio Grande do Sul, Brazil. Four sweet potato cultivars were used in single systems and intercropped with popcorn: BRS Amélia, BRS Rubissol, BRS Cuia and Crioula. The soil fauna assessment was carried out using PROVID-type traps. Richness, abundance and the dominance indices of Shannon (H') and Simpson (D) were determined. The orders Coleoptera, Hymenoptera, Collembola and Orthoptera, were dominant in both cultivation systems. The single cultivation showed a greater number of organisms in the orders Isopoda and Collembola, whereas in the intercropped system, the orders Lepidoptera and Hymenoptera stood out. The intercropping cultivation of sweet potato and popcorn shows highest diversity and abundance of soil organisms compared to the single cultivation.
\end{abstract}

Keywords: diversity; intercrop system; soil organisms; soil quality.

\section{INTRODUCTION}

Agriculture is a fundamental factor in the process of the Brazilian economic development, accounting for $21.4 \%$ of the total Brazilian gross domestic product (Center for Advanced Studies in Applied Economics - CEPEA, 2020). However, a large part of the country's agricultural area is occupied by monocultures, which transform complex natural ecosystems into simplified agro-ecosystems. In this process of environmental conversion, local biodiversity changes since the abundance and diversity of different biological groups are generally associated with the predominant characteristics inherent to environments, such as: soil type, climate and vegetation (Altieri, 2012).

The biological diversity of the soil plays an important role in the decomposition and mineralization of organic residues, favoring the availability of nutrients to plants and even to other organisms (Brown \& Sautter, 2009), through changes in the physical and chemical environment of their habitat (Rezende et al., 2017). The edaphic fauna can be influenced by the cultivation system (Silva et al., 2015; Balin et al., 2017; Costa \& Drescher, 2018), land use (Da Silva et al., 2016; Almeida et al., 2017), fertilization (Alves et al., 2008; Da Silva et al., 2016), among other factors, such as cultural practices, which directly influence the edaphic population (Gatiboni et al., 2009; Silva et al., 2013). This effect may be related to the permanence of organic residues on the soil (Antoniolli et al., 2006), collection period (Da Silva et al., 2016), or even according to the taxonomic group found (Silva et al., 2015; Rezende et al., 2017). It is noticed, therefore, that the soil fauna is sensitive to changes in the environment and can be considered as a good indicator of the biological quality of the soil and useful in the evaluation of agroecosystems (Nunes et al., 2009).

Production systems based on monocultures promote a specific environment for a particular group of fauna organisms, reducing diversity due to the small availability of shelter and the low variety of food resources in the

Submitted on May, $4^{\text {th }} 2020$ and accepted on February $7^{\text {th }}, 2021$

' This work of research was carried in the Agronomy course at the Universidade Estadual do Rio Grande do Sul - UERGS, Três Passos, Rio Grande do Sul, Brazil.

22Universidade Estadual do Rio Grande do Sul, Três Passos, Rio Grande do Sul, Brazil. marcielredin@gmail.com; eduardocanepelle@gmail.com; thaniel.cw@hotmail.com; dannisilva@uergs.edu.br; divanilde-guerra@uergs.edu.br; marta-drescher@uergs.edu.br

*Corresponding author: marcielredin@gmail.com 
local, which provides for the proliferation of organisms that better adapt to these conditions and disrupts the balance of edaphic biodiversity (Baretta et al., 2003; Battirola et al., 2007). In contrast, conservationist managements such as plant intercropping or polycultures, which consist of using two or more different crops in the same area enables the increase in efficiency of land use and the lower frequency of pests and diseases (Altieri, 2012). Plant intercropping tend to offer greater quantity and diversity of residues to the soil, which is reflected in greater availability of food for organisms that live in it (Brito et al., 2016), for this reason it is expected to find greater diversity and abundance of edaphic fauna organisms.

However, there are few studies that evaluate edaphic fauna in intercropped or policultivation cultures (Brito et al., 2016; Rodrigues et al., 2016). Our hypothesis is that the intercropping of sweet potato (Ipomoea batatas) with popcorn (Zea mays) especially when these are conducted in an ecologically-based system favors soil fauna. Thus, the objective of this study was to evaluate the diversity and abundance of edaphic-fauna organisms in single and intercropped systems of sweet potato and ecologically based popcorn in Red Oxisol, in the Northwestern Rio Grande do Sul, Brazil.

\section{MATERIALAND METHODS}

This experiment was carried out in Bom Progresso, Rio Grande do Sul (RS), located at longitude 5351'31.07" $\mathrm{W}$ and latitude $27^{\circ} 33^{\prime} 48.70^{\prime \prime} \mathrm{S}$. The soil of the experimental area is characterized as a typical Red Oxisol (Santos et al., 2018). The climate in the region is of the Cfa type according to the classification of Koppen, with an average annual temperature of $19^{\circ} \mathrm{C}$ and rainfall between 1,800 and 2,000 $\mathrm{mm}$. The experiment was conducted under natural field conditions. The mean rainfall and air temperatures observed during the experimental time are shown in figure 1.

The implantation of sweet potato and popcorn crops was carried out in November 2015, following the region's agroclimatic zoning. The experiment used a randomized block experimental design with three replications in $12 \mathrm{~m}^{2}$ ( 3 x 4m) plots. Four sweet potato cultivars were used: BRS Amélia, BRS Rubissol, BRS Cuia and Crioula. The cultivars were grown in single systems and intercropped with Crioula popcorn in the following treatments: T1 - Crioula sweet potato, T2 - BRS Rubissol, T3 - BRS Amélia, T4 BRS Cuia, T5 - Popcorn, T6 - Crioula sweet potato + Popcorn, T7 - BRS Rubissol + Popcorn, T8 - BRS Amélia + Popcorn, T9 - BRS Cuia + Popcorn.

The sowing of popcorn in the single and intercropped system was carried out in rows, at a spacing of $20 \mathrm{~cm}$ between plants and $75 \mathrm{~cm}$ between rows. Sweet potato cultivars were planted with 3-4 leaf seedlings with a spacing of 25 between plants in the sowing line and $75 \mathrm{~cm}$ between rows. In the intercropped planting, the sweet potato seedlings were arranged in rows in the center of those between rows of popcorn, following the same spacing between plants from single planting (Figure 2).

Fertilization was carried out according to the needs of the soil and established according to the Manual of Fertilization and Liming for the states of Rio Grande do Sul and Santa Catarina of the Soil Chemistry and Fertility Commission, based on the corn crop (Soil Fertility and Chemistry Commission - CQFS RS/SC, 2016). The dose used was $7,000 \mathrm{~kg} / \mathrm{ha}^{-1}\left(4.2 \mathrm{~kg} / \mathrm{plot}^{-1}\right)$ of chicken litter from four plots, divided into two parts, half at sowing/planting and the other half in topdressing, 45 days after planting the sweet-potato cultivars and sowing of popcorn. Spontaneous-growth plants were controlled by weeding every 15 days. The control of pests, basically the caterpillar of the armyworm in popcorn, was necessary three times and carried out using neem oil, but disease control was not necessary.

The evaluation of the edaphic fauna was carried out at the stage of full flowering of popcorn, in February 2016 (Figure 1). The collection was carried out using the "PROVID" method (Antoniolli et al., 2006), the traps being constituted by a 2-L pet bottle, with four windows of 0.06 x $0.04 \mathrm{~m}$, at $0.20 \mathrm{~m}$ from its base. It was added $200 \mathrm{~mL}$ of

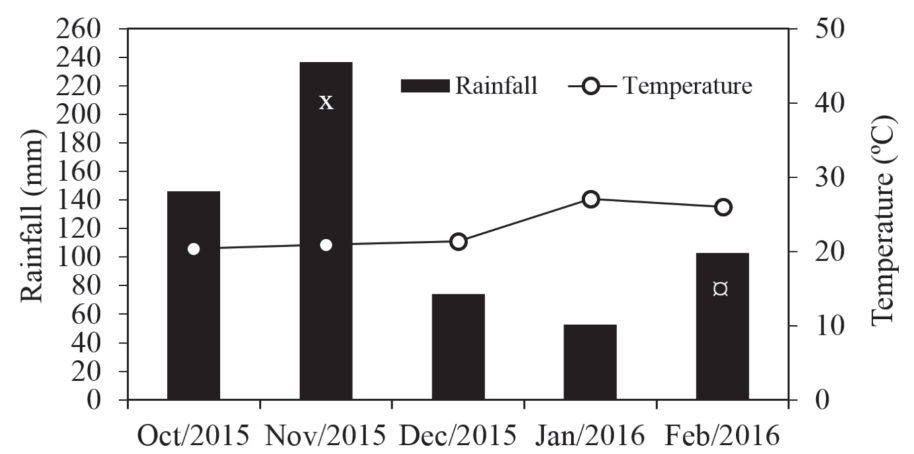

Figure 1: Data of rainfaill and mean air temperature in the experimental time. Source: INMET - National Institute of Meteorology, station in Santo Augusto - RS. Sowing/planting month (x) and soil fauna sampling (æ). 
$70 \%$ alcohol $+2 \mathrm{~mL}$ of glycerin into the trap. Six traps were installed per treatment, between the crop planting lines (Figure 2), which remained in the field for seven days.

The traps collected with the solution containing the captured organisms were taken to the laboratory, and their contents passed through 10- and 100-mesh sieves, to separate the fauna organisms from the soil. Subsequently, the organisms were stored in plastic bottles containing a $70 \%$ alcohol solution, until their identification. The identification in terms of taxonomic order and counting were performed with the stereomicroscope, when richness (number of orders) and abundance (total number of organisms) per treatment were determined.

The edaphic fauna was also evaluated qualitatively by means of the Simpson (D) and Shannon (H') dominance indices, according to Silva et al. (2015). Simpson's dominance index (D), defined as: $\mathrm{D}=\mathrm{ni}(\mathrm{ni}-1) / \mathrm{N}(\mathrm{N}-1)$, where: $\mathrm{ni}=$ density of each order; $\mathrm{N}=$ total number of organisms in the group. Shannon's diversity index is defined as: $\mathrm{H}^{\prime}=-\Sigma($ pi log pi), where: $\mathrm{pi}=\mathrm{ni} / \mathrm{N} ; \mathrm{ni}=$ density of each order; $\mathrm{N}=$ total number of organisms in the group.

The total number of organisms, richness and abundance were subjected to statistical analysis, followed by Skott Knott test at 5\%. Also, the richness, abundance, D and $\mathrm{H}^{\prime}$ between single and intercropped systems were comparted by Student's t test, at 5\%. In addition, the data obtained were submitted to multivariate analysis of principal components to correlate the different orders of soil edaphic organisms with the planting/sowing systems.

\section{RESULTS AND DISCUSSION}

The results of the trap collections showed a total of 971 organisms, belonging to 14 orders, Acarina, Aranae, Coleoptera, Collembola, Chilopoda, Dermaptera, Diplopoda, Hermiptera, Hymenoptera, Isoptera, Isopoda, Orthoptera, and Lepidoptera and Diptera (Table 1).
The orders of organisms that predominated in all treatments were Coleoptera, Hymenoptera, Collembola and Orthoptera, which corresponded to $34.39 \%, 24.09,12.66 \%$ and $10.91 \%$ of the total organisms collected, respectively. These orders corresponded together to $81.23 \%$ of the organisms found in the study, therefore demonstrating their dominance over the other orders of soil organisms. In a study by Brito et al. (2016) the orders Collembola, Diptera and Hymenoptera occurred in a dominant manner in all cultivation systems studied, representing together, more than $80 \%$ of the total relative frequency.

Crioula and BRS Rubissol cultivars showed no increase in the abundance of soil organisms when intercropped with popcorn. However, apart from cultivar BRS Rubissol, the other cultivars showed a greater abundance of organisms when they were submitted to intercropping by Student's t test. According to Silva et al. (2012), this is because the single cultivation system (monoculture), allows a less soil coverage and less total biomass input, which enables an intense solar irradiation, mainly causing high water evaporation from the soil, and consequently, the reduction of soil biodiversity. Silva et al. (2007), highlights that the quantity and quality of plant materials that are deposited in the soil, influence the edaphic fauna. Therefore, the diversity and abundance of the edaphic fauna is benefited by the number of plant species in the area, according to their functionality and the stages of development (Lavelle, 2006; Silva et al., 2013). Correia \& Andrade (1999), also point out that the more diverse the number of species and the more diverse the vegetable cover of the soil, the greater the heterogeneity of the litter, which will also present a greater diversity of soil organisms.

Plant intercropping provides adequate conditions for the development of various orders of soil organisms, as this system provides greater availability of food, due to the large amount and diversity of plant residues that are
Popcorn

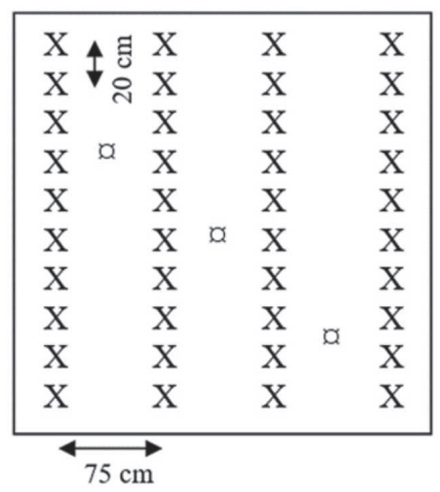

Sweet potato

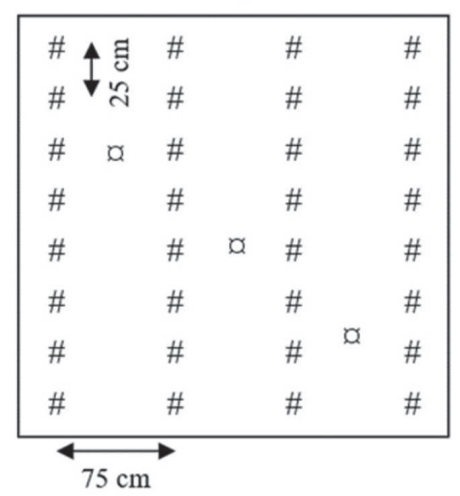

Intercropped

\begin{tabular}{|c|c|c|c|c|c|c|}
\hline $\begin{array}{l}X \\
X\end{array}$ & \# & & \# & 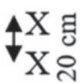 & H & $\begin{array}{l}X \\
X\end{array}$ \\
\hline $\mathrm{X}$ & \# & $\mathrm{X}$ & \# & $\mathrm{X}$ & \# & $\mathrm{X}$ \\
\hline $\mathrm{X}$ & \# & $\mathrm{X}$ & \# & $\mathrm{X}$ & \# & $\mathrm{X}$ \\
\hline $\mathrm{X}$ & \# & $X$ & \# & $X$ & \# & $\mathrm{X}$ \\
\hline $\mathrm{X}$ & \# & $\mathrm{X}$ & \# & $\mathrm{X}$ & \# & $\mathrm{X}$ \\
\hline $\mathrm{X}$ & \# & $\mathrm{X}$ & \# & $\mathrm{X}$ & \# & $\mathrm{X}$ \\
\hline $\mathrm{X}$ & \# & $\mathrm{X}$ & \# & $x_{a}$ & \# & $X$ \\
\hline$X$ & \# & $X$ & \# & X & \# & $\mathrm{X}$ \\
\hline$X$ & \# & $\mathrm{X}$ & \# & $X$ & \# & $\mathrm{X}$ \\
\hline
\end{tabular}

Figure 2: Representative sketch of part of the plots with distribution of popcorn (x), sweet potato plants (\#) and traps ( ) in single and intercropping systems.

Rev. Ceres, Viçosa, v. 68, n.5, p. 484-490, sep/oct, 2021 
brought to the soil. In addition, it creates micro habitats where temperature and humidity conditions are favorable for the development of soil fauna (Silva et al., 2007). In this sense, it is possible to understand why the sweet potato cultivars Crioula, BRS Rubissol and BRS Cuia presented greater diversity of soil organisms when cultivated in the system intercropped with popcorn. Brito et al. (2016), found that the intercropped cultivation of cassava (Manihot esculenta) with millet (Pennisetum glaucum) resulted in an increase in the diversity of soil organisms and that the single cultivation of cassava reduced the richness of soil organisms, due to the absence of vegetation cover and low deposition of plant residues.

The intercropping of popcorn with the cultivars of sweet potato, except BRS Amélia, resulted in a greater richness of organisms. In a study by Rodrigues et al. (2016), the diversity of the edaphic fauna was influenced by the vegetation coverings in the different agroecosystems, where the polyculture area was analyzed, providing a greater diversity of arthropods of the edaphic fauna. In the study by Santos (2009), it was observed that the turnip (Raphanus sativus)/black oats (Avena strigosa) and vetch (Vica sativa)/turnip/black oats intercropping promoted a greater diversity of organisms in the edaphic fauna, when compared to fallow. On the other hand, the sweet potato cultivar BRS Amélia showed same diversity of orders in single and intercropped systems. This result can be attributed to the high biomass supply of this sweet potato cultivar (data not shown), thus, indicating that the single cultivation of this cultivar provides soil coverage at levels satisfactory to the biological demand of the soil, so that it does not need a companion crop in intercropping for soil protection.

According to Antoniolli et al. (2006), the Collembola species specifically have an enormous importance in the balance of ecosystems, as they are considered primary and secondary decomposers, acting in the fragmentation and reduction of vegetal debris, thus favoring the action of fungi and bacteria in the decomposition process of organic residues in the soil. Balin et al. (2017), showed that in different tillage systems and different soil cover plants the most frequent edaphic fauna organisms were also those of the order Collembola, regardless of treatments and collection time. For Balin et al. (2017), cover plants influence the diversity and abundance of edaphic fauna, as well as the different collection periods, mainly due to the different food supply in each sample period. Thus, the predominance of this order in the present study is justified, given the large amount of vegetation cover and high biomass apport specifically in the intercropping systems at the evaluation period.

The use of an ecologically-based production system, in which the fertilization was the organic using chicken litter, may also have contributed to a greater abundance of organisms, especially of the Collembola. Cutz-pool et al. (2007), found that the addition of chicken litter to the

Table 1: Average number of edaphic fauna organisms collected in treatments T1 - Crioula sweet potato, T2 - BRS Rubissol, T3 - BRS Amélia, T4 - BRS Cuia, T5 - Popcorn, T6 - Crioula sweet potato + Popcorn, T7 - BRS Rubissol + Popcorn, T8 - BRS Amélia + Popcorn and T9 - BRS Cuia + Popcorn.

\begin{tabular}{|c|c|c|c|c|c|c|c|c|c|c|}
\hline \multirow{2}{*}{ Orders } & \multicolumn{9}{|c|}{ Treatments } & \multirow{2}{*}{ Total } \\
\hline & T1 & $\mathbf{T 2}$ & T3 & T4 & T5 & T6 & T7 & T8 & T9 & \\
\hline $\mathrm{AC}^{1}$ & 2 & 4 & 2 & 2 & 1 & 3 & 4 & 3 & 3 & $24 \mathrm{C}^{*}$ \\
\hline $\mathrm{AR}$ & 4 & 2 & 2 & 0 & 2 & 2 & 8 & 2 & 2 & $24 \mathrm{C}$ \\
\hline $\mathrm{CP}$ & 41 & 41 & 25 & 35 & 28 & 47 & 41 & 32 & 44 & $334 \mathrm{~A}$ \\
\hline $\mathrm{CL}$ & 23 & 19 & 8 & 14 & 32 & 12 & 3 & 3 & 9 & $123 \mathrm{~A}$ \\
\hline $\mathrm{CH}$ & 0 & 0 & 0 & 0 & 0 & 1 & 0 & 0 & 0 & $1 \mathrm{C}$ \\
\hline $\mathrm{DE}$ & 1 & 4 & 2 & 2 & 2 & 3 & 4 & 4 & 3 & $25 \mathrm{C}$ \\
\hline DP & 0 & 0 & 0 & 0 & 0 & 0 & 1 & 0 & 0 & $1 \mathrm{C}$ \\
\hline $\mathrm{HE}$ & 2 & 3 & 1 & 0 & 1 & 1 & 2 & 2 & 1 & $13 \mathrm{C}$ \\
\hline HY & 22 & 24 & 29 & 22 & 20 & 30 & 25 & 32 & 30 & $234 \mathrm{~A}$ \\
\hline IS & 2 & 4 & 2 & 3 & 3 & 3 & 4 & 4 & 3 & $28 \mathrm{C}$ \\
\hline IP & 1 & 0 & 0 & 1 & 1 & 1 & 0 & 0 & 0 & $4 \mathrm{C}$ \\
\hline OR & 15 & 21 & 3 & 14 & 8 & 14 & 19 & 6 & 6 & $106 \mathrm{~B}$ \\
\hline LP & 1 & 3 & 2 & 1 & 2 & 1 & 3 & 4 & 3 & $20 \mathrm{C}$ \\
\hline DI & 2 & 6 & 3 & 5 & 3 & 4 & 3 & 3 & 5 & $34 \mathrm{C}$ \\
\hline Richness & $12 \mathrm{~B} \mathrm{~b}$ & $11 \mathrm{Cb}$ & $11 \mathrm{C} \mathrm{a}$ & $10 \mathrm{D} \mathrm{b}$ & $12 \mathrm{~B}$ & $13 \mathrm{Aa}$ & $12 \mathrm{~B} \mathrm{a}$ & $11 \mathrm{C} \mathrm{a}$ & $11 \mathrm{Ca}$ & \\
\hline Abundance & $116 \mathrm{~A} \mathrm{~b}$ & $131 \mathrm{~A} \mathrm{a}$ & $79 \mathrm{D} \mathrm{b}$ & $99 \mathrm{C} \mathrm{b}$ & $103 \mathrm{~B}$ & $122 \mathrm{~A} \mathrm{a}$ & $117 \mathrm{~A} \mathrm{~b}$ & $95 \mathrm{C} \mathrm{a}$ & $109 \mathrm{~B} \mathrm{a}$ & \\
\hline
\end{tabular}

${ }^{1}$ AC: Acarina; AR: Aranae; CP: Coleoptera; CL: Collembola; CH: Chilopoda; DE: Dermaptera; DP: Diplopoda; HE: Hemiptera; HY: Hymenoptera; IS: Isoptera; IP: Isopoda; OR: Orthoptera; LP: Lepidoptera e DI: Diptera. *Same uppercase letters in the column total, lines for richness and abundance are not statistically different by the Skott Knott and lowercase in the lines (T1 x T6, T2 x T7, T3 x T8 and T4 x T9) by Student's t test, both at 5\%. 
soil as a fertilizer, besides resulting in improvements in the chemical characteristics of the soil, it also benefited the development of the populations of Collembola species. Baretta et al. (2003), also demonstrated that the use of organic fertilizers promotes the maintenance of the edaphic fauna, and in some cases benefit the development of certain orders of organisms, such as Collembola species. Silva et al. (2013), concluded that the use of turnip/black oat and vetch/turnip/black oat intercropping promoted an increase in the abundance of organisms and the number of Collembola species in the early stages. Da Silva et al. (2016), observed that the pasture area using pig slurry for 14 years, the Collembola species represented up to $71.93 \%$ of the total average number of collected organisms.

Regarding the diversity indexes, it was observed that most sweet potato cultivars showed a higher Shannon index (H') and Simpson's dominance (D) when they were submitted to the intercropping with popcorn (Table 2).

According to Silva et al. (2015), the number of orders (diversity) is one of the variables that is considered to determine the Shannon's index. Thus, it is a fact that the intercropping showed higher values of H' when compared to the single cultivation (except BRS Cuia - T9), since only the sweet potato cultivar BRS Amélia did not present a higher number of orders when it was submitted to the intercropped system. Also, according to Silva et al. (2015), conditions that provide the largest number of organism orders, naturally tends to have higher H' values, so it can be understood why the intercropping system presented the highest H' values. Brito et al. (2016) who evaluated the cultivation of cassava in the single system and intercropped with jack bean (Canavalia ensiformis), millet and dwarf pigeonpea (Cajanus cajan) did not observe higher values of H'in the intercropped system, due to the dominance of the orders Collembola, Hymenoptera and Diptera, which caused a reduction in H'. Likewise, Silva et al. (2013) reported that the vetch/turnip/black oat intercropping reduced Shannon's diversity by increasing the population of springtails. Almeida et al. (2017), in an area that received the addition of large volumes of poultry litter also showed less diversity of organisms, due to the occurrence of a high population of springtails.
As for the Simpson index (D), only the sweet potato cultivar BRS Amélia - T8 showed a lower dominance index when intercropped with popcorn. The different information that is observed when comparing the two studied indexes is expected, since the diversity index H'is extremely influenced by the orders that present less frequency, while the index D is influenced by the orders found in greater frequency, or in dominant abundance. According to Rodrigues et al. (2017), high values of the H'and D indices for polyculture areas indicate more uniform communities, where the dominance of one or a few groups is reduced, these results are important references for the farmer to continue with the management of plant residues, which make up the main source of food and habitat for most of the species living in the soil.

The table 1 showed that the single cultivation of sweet potato cultivars provided the development of a greater number of organisms of the orders Isopoda and Collembola, whereas the intercropping of sweet potato cultivars with popcorn provided a more favorable environment for the development of organisms of the orders Dermaptera, Diptera and Hymenoptera. This finding was also observed in the analysis of the principal components (Figure 3 ).

The data of the edaphic fauna when analyzed by means of analysis of the principal components showed that $61 \%$ of the total variation of the data occurred in the first two principal components. PC 1 explained $41 \%$ of the variation in the data and clearly separated the orders Isopoda and Collembola in the negative quadrant and directly correlated to the single crops. Also, in PC1, the intercropping was clearly separated, except popcorn + Crioula sweet potato, in the positive quadrant and directly correlated to orders Lepidoptera and Hymenoptera. In PC 2 , with $20 \%$ of the data variation, the corn popcorn + Crioula sweet potato intercropping separated in the negative quadrant and inversely correlated to the order Orthoptera. In a study by Da Silva et al. (2016) PC 1 explained 54.24\% of the data variability and included Coleoptera, Diptera and Collembola among its biological variables. For Silva et al. (2015), the taxonomic groups Coleoptera, Hemiptera, Diptera, Hymenoptera and Isopoda were considered as

Table 2: Indices of Shannon's ecological diversity (H') and Simpson's dominance (D) of edaphic fauna organisms in treatments T1: Crioula sweet potato; T2: BRS Rubissol; T3: BRS Amélia; T4: BRS Cuia; T5: Popcorn; T6: Crioula sweet potato + Popcorn; T7: BRS Rubissol + Popcorn; T8: BRS Amélia + Popcorn and T9: BRS Cuia + Popcorn.

\begin{tabular}{lccccccccc}
\hline \multirow{2}{*}{ Indices } & \multicolumn{10}{c}{ Treatments } \\
\cline { 2 - 11 } & T1 & T2 & T3 & T4 & T5 & T6 & T7 & T8 & T9 \\
\hline H' $^{\prime}$ & $0.76 \mathrm{~b}^{*}$ & $0.83 \mathrm{~b}$ & $0.75 \mathrm{~b}$ & $0.77 \mathrm{a}$ & 0.78 & $0.78 \mathrm{a}$ & $0.84 \mathrm{a}$ & $0.78 \mathrm{a}$ & $0.76 \mathrm{a}$ \\
$\mathrm{D}$ & $0.21 \mathrm{~b}$ & $0.18 \mathrm{~b}$ & $0.24 \mathrm{a}$ & $0.21 \mathrm{~b}$ & 0.21 & $0.23 \mathrm{a}$ & $0.20 \mathrm{a}$ & $0.23 \mathrm{a}$ & $0.25 \mathrm{a}$ \\
\hline
\end{tabular}

*Means followed by the same lowercase letter on lines indices between single and intercropped crops (T1 x T6, T2 x T7, T3 x T8 and T4

$\mathrm{x}$ T9) do not differ statistically, by Student's t test, at 5\%.

Rev. Ceres, Viçosa, v. 68, n.5, p. 484-490, sep/oct, 2021 

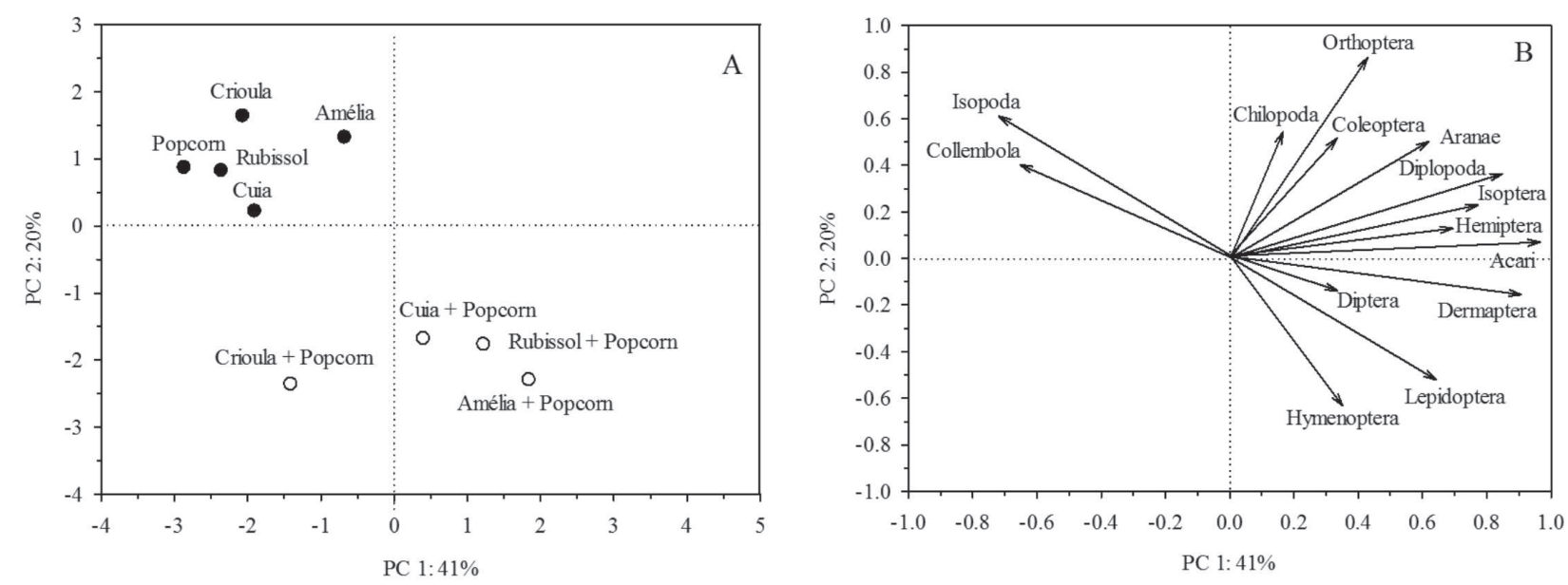

Figure 3: Factorial map (A) and circle correlation (B) obtained from the analysis of principal components 1 and 2 (PC 1 and PC 2) carried out with the soil edaphic fauna data in the single and intercropped systems of sweet potato and popcorn.

the best bioindicators of edaphic quality in the different land uses tested in the border region of the plateau in the state of Rio Grande do Sul.

Agricultural production systems within each agroecosystem seek greater resilience in the productive system, especially in the soil. Single or intercropped systems as well as the quality and quantity of cultural residues in the soil, may be able to directly influence organisms in the soil. According to the results and initial hypothesis in our study, the popcorn-sweet potato intercropping tends to have a greater diversity of organisms, due to the greater amount and diversity of plant residues, which are intrinsically associated with the appropriate conditions for the development and balance of species richness in the soil environment. Therefore, this type of cultivation tends to promote a greater ecological balance of the soil edaphic fauna, promoting numerous benefits to the agro-ecosystem, particularly the quality of the soil.

\section{CONCLUSIONS}

The orders Coleoptera, Hymenoptera, Collembola and Orthoptera presented themselves as dominant in the single and intercropped systems of sweet potato and popcorn.

The single cultivation of popcorn and sweet potato favors the orders Isopoda and Collembola. On the other hand, the intercropping promoted the Lepidoptera and Hymenoptera.

The intercropping cultivation of sweet potato and popcorn shows highest diversity and abundance of soil organisms compared to the single cultivation.

\section{ACKNOWLEDGEMENTS, FINANCIAL SUPPORT AND FULL DISCLOSURE}

Thanks to Pró Reitoria de Pós Graduação e Pesquisa (PROPPG) of Universidade Estadual do Rio Grande do Sul
(UERGS) for the scholarship award of CNPq and FAPERGS, essential for execution this research under field conditions. There is no conflict of interest in conducting and publishing the paper.

\section{REFERENCES}

Altieri M (2012) Agroecologia: bases científicas para uma agricultura sustentável. $3^{\text {rd }}$ ed. Rio de Janeiro, AS-PTA. 400p.

Alves MV, Santos JCP, Gois DT, Alberton JV \& Baretta D (2008) Macrofauna do solo influenciada pelo uso de fertilizantes químicos e dejetos de suínos no oeste do estado de Santa Catarina. Revista Brasileira de Ciência do Solo, 32:589-598.

Almeida HS, Silva RF, Grolli AL \& Scheid DL (2017) Ocorrência e diversidade da fauna edáfica sob diferentes sistemas de uso do solo. Revista Brasileira de Tecnologia Agropecuária, 1:15-23.

Antoniolli ZI, Conceição PC, Böck V, Silva DM \& Silva RF (2006) Método alternativo para estudar a fauna do solo. Ciência Florestal, 16:407-417.

Balin NM, Bianchin C, Ziech ARD, Luchese AV, Alves MV \& Conceição PC (2017) Fauna edáfica sob diferentes sistemas de manejo do solo para produção de cucurbitáceas. Scientia Agraria, 18:74-84

Baretta D, Santos JCP, Mafra AL, Wildner LP \& Miquelleti DJ (2003) Fauna edáfica avaliada por armadilhas e catação manual afetada pelo manejo do solo na região oeste catarinense. Revista de Ciências Agroveterinárias, 2:97-106.

Battirola LD, Adis J, Marques MI \& Silva FHO (2007) Comunidade de artrópodes associada à copa de Attalea phalerata Mart. (Arecaceae) durante o período de cheia no Pantanal de Poconé, MT. Neotropical Entomology, 36:640-651.

Brito MF, Tsujigushi BP, Otsubo AA, Silva RF \& Mercante FM (2016) Diversidade da fauna edáfica e epigeica de invertebrados em consórcio de mandioca com adubos verdes. Pesquisa Agropecuária Brasileira, 51:253-260.

Brown GG \& Sautter KD (2009) Biodiversity, conservation and sustainable management of soil animals. Pesquisa Agropecuária Brasileira, 44:1-9.

CEPEA - Centro de Estudos Avançados em Economia Aplicada (2020) Pib do agronegócio brasileiro. Available at: https:// www.cepea.esalq.usp.br/br/pib-do-agronegocio-brasileiro.aspx. Accessed on: March 27th, 2020.

Rev. Ceres, Viçosa, v. 68, n.5, p. 484-490, sep/oct, 2021 
Correia MEF \& Andrade AG (1999) Formação de serapilheira e ciclagem de nutrientes. In: Santos GA, Silva L, Canellas LP \& Camargo FAO (Ed.) Fundamentos da matéria orgânica do solo: Ecossistemas tropicais e subtropicais. Porto Alegre, Gênesis. p. 197-225.

Costa LM \& Drescher MS (2018) Implications of agricultural management on the epigeic fauna and soil physical properties of a clayey Oxisol. Revista Ceres, 65:443-449.

Cqfs - Comisão de Química e Fertilidade do Solo (2016) Manual de Calagem e Adubação para os Estados do Rio Grande do Sul e de Santa Catarina. Porto Alegre, SBCS. 376p.

Cutz-Pool LQ, Vargas JGP, Meneses GC \& García-Calderón NE (2007) Edaphic Collembola from two agroecosystems with contrasting irrigation type in Hidalgo State, Mexico. Applied Soil Ecology, 36:46-52.

Da Silva DM, Jacques RJS, Da Silva DAA, Santana NA, Vogelmann E, Eckhardt DP \& Antoniolli ZI (2016) Effects of pig slurry application on the diversity and activity of soil biota in pasture areas. Ciência Rural, 46: 1756-1763.

Gatiboni LC, Coimbra JML, Wildner LP \& Denardin RBN (2009) Modificações na fauna edáfica durante a decomposição da palhada de centeio e aveia-preta, em sistema plantio direto. Biotemas, 22:45-53

Lavelle P, Decaëns T, Aubert M, Barot S, Bulouin M, Bureau F, Margerie P, Mora P \& Rossi J-P (2006) Soil invertebrates and ecosystem services. European Journal of Soil Biology, 42:3-15.

Nunes LAPL, De Araújo Filho JA \& De Queiroz RÍM (2009) Diversidade da fauna edáfica em solos submetidos a diferentes sistemas de manejo no semi-árido nordestino. Scientia Agraria, 10:43-49.
Rezende LP, Portela GF, Macedo NC \& Dourado K (2017) Identificação da macrofauna do solo em pastagem de Panicum maximum jacq. e área submetida à queimada no município de Sambaíba-MA. Biodiversidade, 16:21-32.

Rodrigues DM, Ferreira LO, Silva NR, Guimarães ES, Martins ICF \& Oliveira FA (2016) Diversidade de artrópodes da fauna edáfica em agroecossistemas de estabelecimento agrícola familiar na Amazônia Oriental. Revista de Ciências Agrárias, 59:32-38.

Santos HG, Jacomine PKT, Dos Anjos LHC, De Oliveira VA, Lumbreras JF, Coelho MR \& Cunha TJF (2018) Sistema Brasileiro de Classificação de Solos. $5^{\text {th }}$ ed. Brasília, Embrapa. 356p.

Santos CAB (2009) Consórcios de espécies de cobertura de solo para adubação verde antecedendo o cultivo milho e repolho sob manejo orgânico. Master Dissertation. Universidade Federal do Rio de Janeiro, Seropédica. 66p.

Silva DAA, Da Silva DM, Jaques RJS \& Antoniolli ZI (2015) Bioindicadores de qualidade edáfica em diferentes usos do solo. Enciclopédia Biosfera, 11:3728- 3736.

Silva J, Jucksch I, Feres CIMA \& Tavares RC (2012) Fauna do solo em sistemas de manejo com café. Journal of Biotechnology and Biodiversity, 3:59-71.

Silva RF, Corassa GM, Bertollo GM, Santi AL \& Steffen RB (2013) Fauna edáfica influenciada pelo uso de culturas e consórcios de cobertura do solo. Pesquisa Agropecuária Tropical, 43:130-137.

Silva RF, Tomazi M, Pezarico CR, Aquino AM \& Mercante FM (2007) Macrofauna invertebrada edáfica em cultivo de mandioca sob sistemas de cobertura do solo. Pesquisa Agropecuária Brasileira, 42:865 871 . 